\title{
THE MORPHOMETRY OF THE LUMBAR COSTIFORM PROCESS
}

\section{Bizadea Mihaela', Nișcoveanu Cosmin', Bordei Petru'}

${ }^{1}$ Faculty of Medicine, University "Ovidius" of Constanţa

Mihaela Bizadea

Faculty of Medicine, Univeristy ,, Ovidius” of Constanta, Universitatii Alee No. 1, Campus B, Constanta, Romania email:miha.bizadea@gmail.com phone: +40740771718

\begin{abstract}
The length of the lumbar costiform process was determined and compared at the right and left side of the body, according to sex, on 32 cases. Differences were found, some were significant, depending on the side of the body. For both sexes, a gradual growth of the general average for the right and left lumbar costiform process was observed only for the first three vertebras, the value at the level of the last two lumbar vertebras being smaller than at the level of the L3 vertebra.
\end{abstract}

Keywords: lumbar vertebras, costiform process, length

\section{Introduction}

The costiform processes (Processus costiformis; Processus costalis) are rests of the ribs, being large quadrilateral (rectangular) and flat on the anterior and posterior side, arranged in frontal part $(1,2,3,4)$; the L2 and the L3 costiform processes are better represented (5).

\section{Objective}

The purpose of the study is to determine the costiform process length and to compare the right with the left lumbar costiform process length, according to sex.

\section{Material and method}

The morphometry was realized in the anatomy laboratory of the Medicine University of Constanta using direct measurements on the bone segment (lumbar vertebra) with a scale ribbon and a slide rule but also by $\mathrm{CT}$ scans made on a VCT Lightspeed facility of 64 slices, created by General Electric. The length of the right and left costiform process was compared according with the sex on 32 cases, the results being compared in millimeters. 


\section{Results}

The lumbar right costiform process length was between 4.6-18.1 mm.

At the level of the L1 right lumbar vertebra the costiform process length was between 11.0$29.7 \mathrm{~mm}$, for the female the length was between 11.0-23.4 mm, and at the male was between 17.7$29.7 \mathrm{~mm}$. (Figure 3, 4)

At the level of the L2 right lumbar vertebra the costiform process length was between 15.0$31.8 \mathrm{~mm}$, for the female the length was between $15.0-31.8 \mathrm{~mm}$, and at the male was between 18.9-31.8 mm. (Figure 3, 4)

At the level of the L3 right lumbar vertebra the costiform process length was between 16.1$34.5 \mathrm{~mm}$, for the female the length was between 16.1- $34.5 \mathrm{~mm}$, and at the male was between 24.6 $-34.5 \mathrm{~mm}$. (Figure 3, 4)

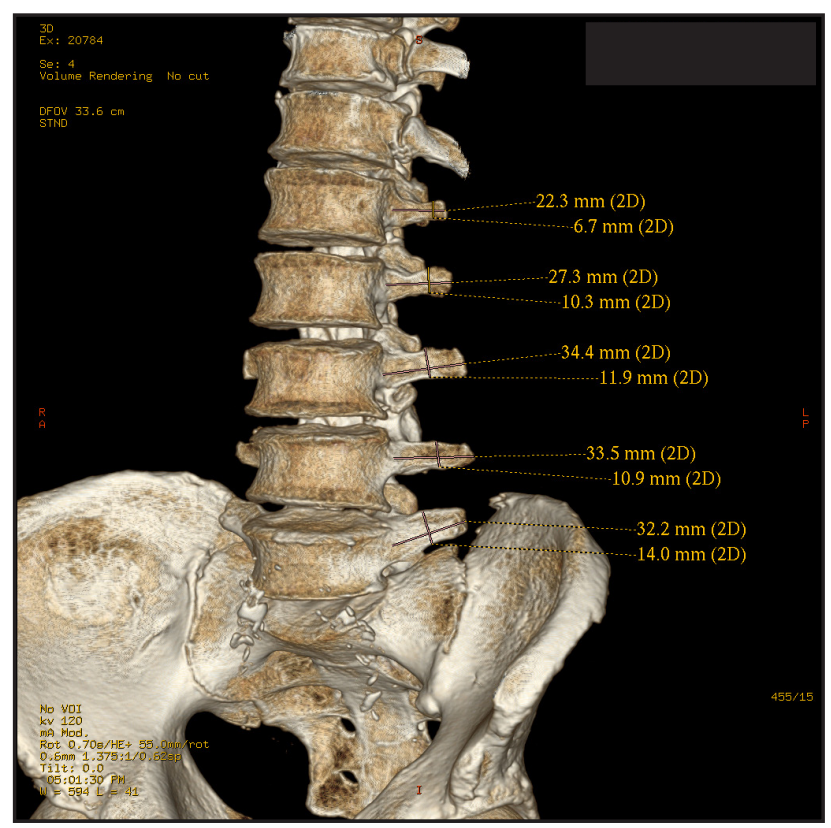

Figure 1 The length of the left costiform L1 process is $22.3 \mathrm{~mm}$ and the width is $6.7 \mathrm{~mm}$; the length of the left costiform L2 process is $27.3 \mathrm{~mm}$ and the width is 10.3 $\mathrm{mm}$; the length of the left costiform L3 process is $34.4 \mathrm{~mm}$ and the width is $11.9 \mathrm{~mm}$; the length of the left L4 process is $33.5 \mathrm{~mm}$ and the width is $10.9 \mathrm{~mm}$; the length of the left costiform process L5 is $32.2 \mathrm{~mm}$ and the width is $14.0 \mathrm{~mm}$ (male)

At the level of the L4 right lumbar vertebra the costiform process length was between 10.7$32.2 \mathrm{~mm}$, for the female the length was between 10.7-29.1 $\mathrm{mm}$, and at the male was between 22.1-32.2 mm. (Figure 3, 4)
At the level of the L5 right lumbar vertebra the costiform process length was between 17.8$37.1 \mathrm{~mm}$, for the female the length was between $17.8-28.8 \mathrm{~mm}$, and at the male was between 19.9-37.1 mm. (Figure 3, 4)

The lumbar left costiform process length was between 10.7-35.7 mm.

At the level of the L1 left lumbar vertebra the costiform process length was between 10.7$29.7 \mathrm{~mm}$, for the female the length was between 10.7-25 mm, and at the male was between 16.3$29.7 \mathrm{~mm}$. (Figure 1, 2, 3, 4)

At the level of the L2 left lumbar vertebra the costiform process length was between 18.4$30.2 \mathrm{~mm}$, for the female the length was between 18.4-30.2mm, and at the male was between 21.3$30.2 \mathrm{~mm}$. (Figure 1, 2, 3, 4)

At the level of the L3 left lumbar vertebra the costiform process length was between 19.6$35.7 \mathrm{~mm}$, for the female the length was between 19.6-32 mm, and at the male was between 27.6$35.7 \mathrm{~mm}$. (Figure 1, 2, 3, 4)

At the level of the L4 left lumbar vertebra the costiform process length was between 17 $33.5 \mathrm{~mm}$, for the female the length was between $17.0-24.2 \mathrm{~mm}$, and at the male was between 20.6-33.5 mm. (Figure 1, 2, 3, 4)

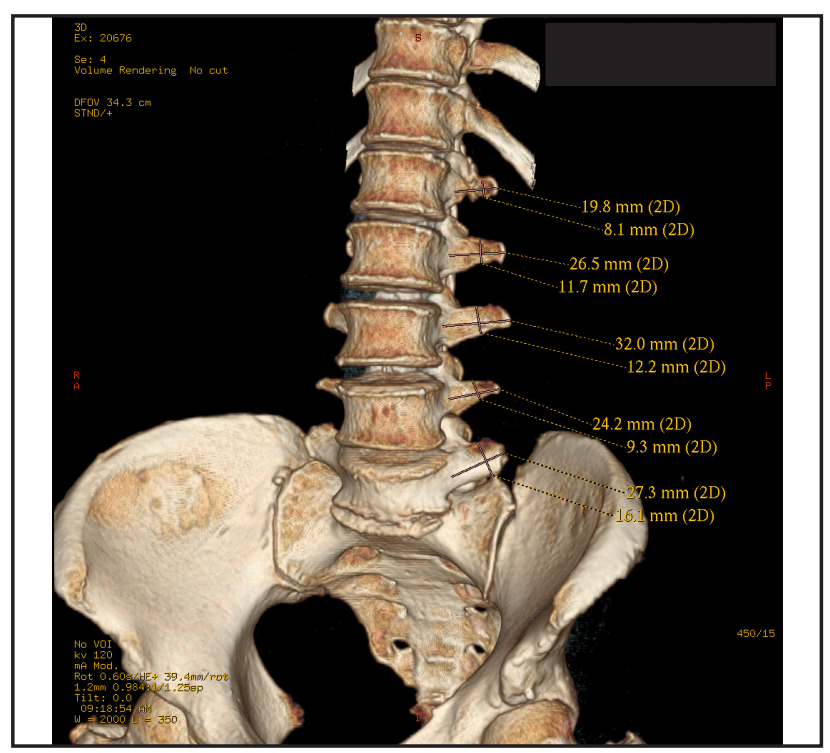

Figure 2 The length of the left costiform L1 process is $19.8 \mathrm{~mm}$ and the width is $8.1 \mathrm{~mm}$; the length of the left $\mathrm{L2}$ process is $26.5 \mathrm{~mm}$ and the width is $11.7 \mathrm{~mm}$; the length of the left costiform L3 process is $32.0 \mathrm{~mm}$ and the width is $12.2 \mathrm{~mm}$; the length of the left costiform L4 process is $24.2 \mathrm{~mm}$ and the width is $9.3 \mathrm{~mm}$; the length of the left L5 costiform process is $27.3 \mathrm{~mm}$ and the width is $16.1 \mathrm{~mm}$ (female) 
At the level of the L5 left lumbar vertebra the costiform process length was between 13.4$32.2 \mathrm{~mm}$, for the female the length was between 13.4-27.3 $\mathrm{mm}$, and at the male was between 22.6-32.2 mm. (Figure 1, 2, 3, 4)

\section{Discussions}

The length of the right and left costiform process was compared and differences were found, some significant between the two sides of the body.

At the level of the L1 costiform, from 21 cases the right costiform was longer than the left one with $0.3-2.9 \mathrm{~mm}$. In the other 11 cases the left costiform was longer with $1.0-2.5 \mathrm{~mm}$.

\section{(Figure 3, 4)}

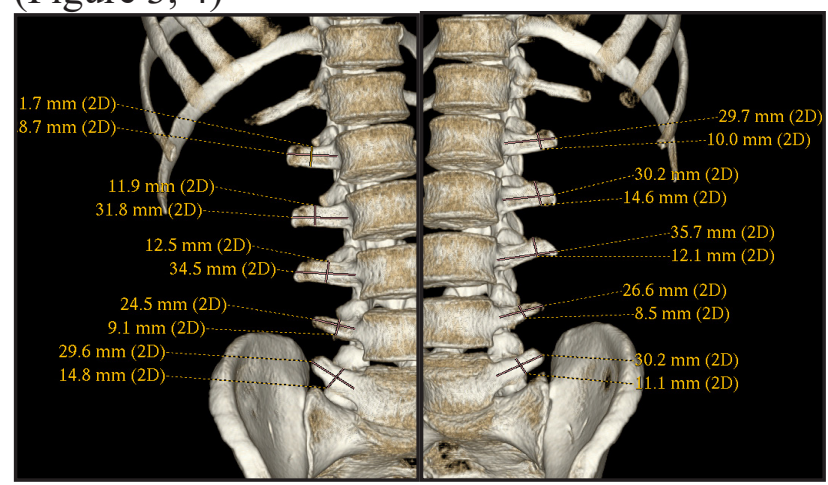

Figure 3 The right costiform L1 is longer than the right one with $1.0 \mathrm{~mm}$, the right costiform L2 is longer than the left one with $1.6 \mathrm{~mm}$, the L3 left costiform is longer than the right one with $1.2 \mathrm{~mm}$, the L4 left costiform is longer than the right one with $2.1 \mathrm{~mm}$, the L5 left costiform is

longer than the right one with $0.6 \mathrm{~mm}$ (male)

At the level of the L2 costiform, from 21 cases the right costiform was longer than the left one with $0.3-3.4 \mathrm{~mm}$. In the other 11 cases the left costiform was longer with $0.7-1.7 \mathrm{~mm}$. (Figure 3, 4)

At the level of the L3 costiform, from 15 cases the right costiform was longer than the left one with $0.4-1.0 \mathrm{~mm}$. In the other 13 cases the left costiform was longer with $0.2-1 \mathrm{~mm}$. In 4 cases the right and the left costiform were equal. (Figure 3, 4)

At the level of the L4 costiform, from 17 cases the right costiform was longer than the left one with $0.5-4.9 \mathrm{~mm}$. In the other 15 cases the left costiform was longer with $1.5-2.1 \mathrm{~mm}$. (Figure 3, 4)

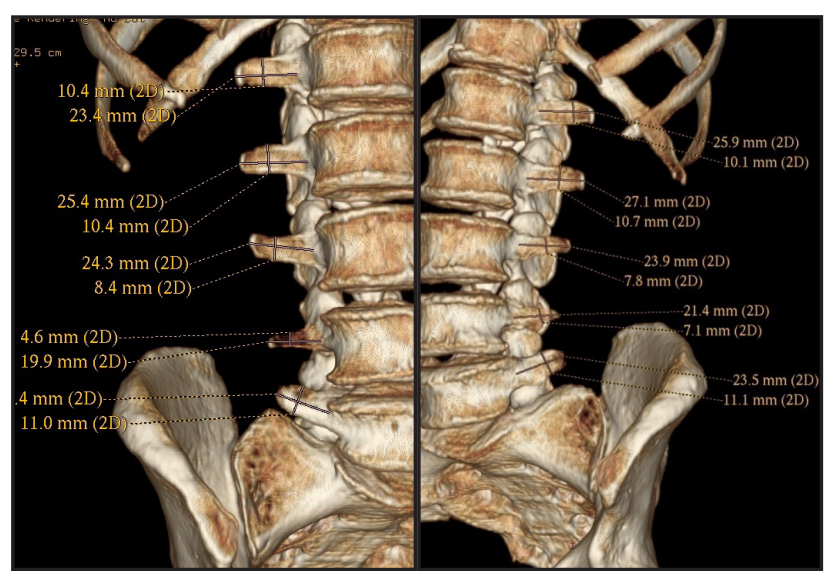

Figure 4 The Left costiform L1 is longer than the right one with $2.5 \mathrm{~mm}$; the left costiform L2 is longer than the right one with $1.7 \mathrm{~mm}$; the right costiform L3 is longer than the left one with $0.4 \mathrm{~mm}$; the left costiform L4 is longer than the right one with $1.5 \mathrm{~mm}$; the left costiform L5 is longer than the right one with $2.1 \mathrm{~mm}$ (female)

At the level of the L5 costiform, from 15 cases the right costiform was longer than the left one with $1.5-4.9 \mathrm{~mm}$. In the other 17 cases the left costiform was longer with 0.6-2.7 $\mathrm{mm}$. (Figure 3, 4)

$(1,3,4,5,6,7,8)$ are described the lumbar costiform process, as being bulky, long and narrow, and (5) considers that L2 and L3 are best represented, the shortest being the L1 costiform process. I found that the shortest costiform process was at the level of the L1 left costiform and at the level of the L4 right costiform, both of which were female and the value was $10.7 \mathrm{~mm}$.

\section{Conclusions}

At the level of the right costiform process the average length was $23.93 \mathrm{~mm}$, for the male was $25.92 \mathrm{~mm}$ and for the female was $21.53 \mathrm{~mm}$.

For the male the average length of the right lumbar costiform process was between 22.48 $\mathrm{mm}$ (for the L1) and $29.54 \mathrm{~mm}$ (for the L3). For the female the average length of the right lumbar costiform process was between $17.56 \mathrm{~mm}$ (for the L1) and $24.18 \mathrm{~mm}$ (for the L3). For both sexes we observe a gradual growth of the value of the average length only at the level of the first three right vertebras, the value of the last two lumbar vertebras being smaller than at the level of the L3 vertebra.

At the level of the left costiform process the average length was $24.18 \mathrm{~mm}$, for the male 
was $26.03 \mathrm{~mm}$ and for the female was $21.78 \mathrm{~mm}$. For the male the average length of the general averages of the left lumbar costiform process was between $21.92 \mathrm{~mm}$ (for the L1) and 30.62 $\mathrm{mm}$ (for the L3). For the female the average length of the general averages of the left lumbar costiform process was between $18.30 \mathrm{~mm}$ (for the L1) and $25.16 \mathrm{~mm}$ (for the L3). As for the right costiform, we observe a gradual growth of the value of the average length only at the level of the first three left vertebras, the value of the last two lumbar vertebras being smaller than at the level of the L3 vertebra.

\section{References}

1. Papilian V. Anatomia omului. Volumul I Aparatul locomotor. Bucuresti: Ed. All; 1998

2. Bordei P, Iliescu D, Şapte E. Scheletul corpului uman. Constanta: Ed. "Ovidius" University Press; 2004

3. Moore K, Dalley A. Colonne vertébrale. In: Anatomie Médicale. Aspects fondamentaux et applications cliniques. Bruxelles: Ed. De Boeck Université; 2001

4. Robacki R. Anatomia funcţională a omului. Vol. I. Anatomia generală şi aparatul locomotor. Craiova: Ed. Scrisul Românesc; 1985

5. Diaconescu N, Veleanu C, Klepp HJ. Coloana vertebrală. Bucuresti: Ed. Medicală; 1977

6. Rouvière H, Delmas A. Colonne vertébrale. In: Anatomie Humaine. Descriptive, topographique et fonctionnelle. Tome II. Tronc. Paris: Ed. Masson; 1997

7. Louis R, Bouchet A. Colonne vertébrale Sacrum - Coocyx. In: JPChevrel. Anatomie Clinique. Le Tronc. New York: Ed. SpringlerVerlag Paris; 1994

8. Standring S. Gray's Anatomy. TheAnatomical Basis of Clinical Practice. Edinburg: Ed. Elsevier-Churchill Livingstone; 2005

9. Terminologia Anatomica. International Anatomical Terminology èd. Thieme Stuttgart. New York, 1998 